
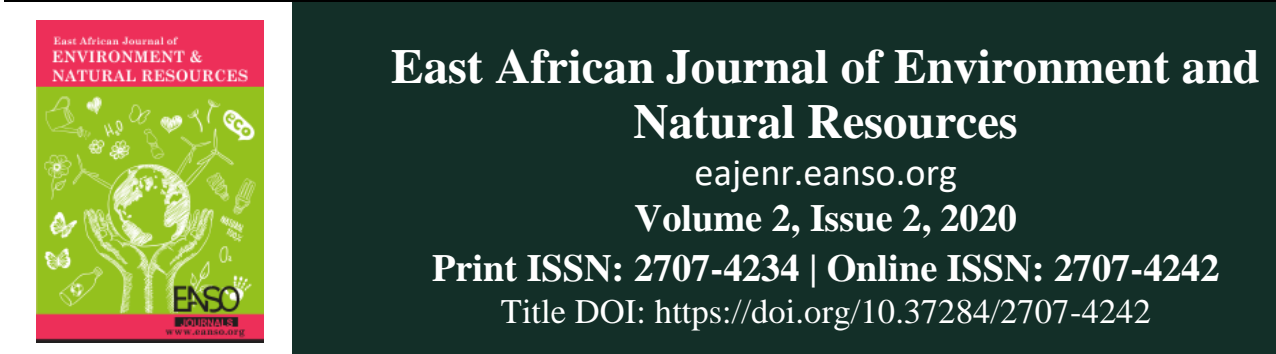

Original Article

\title{
Analysis of the Impact of Built Environment on Coastline Ecosystem Services and Values
}

\author{
Mkama Thomas Manyama ${ }^{*}$, Cuthbert Leonard Nahonyo, $P h D^{1} \&$ Aloyce Shaban Hepelwa, PhD ${ }^{l}$ \\ ${ }^{1}$ University of Dar es Salaam, P. O. Box 35064, Dar es Salaam, Tanzania. \\ * Author for Correspondence email: mkama.ma@gmail.com \\ * ORCID: https://orcid.org/0000-0003-3349-8055
}

Article DOI: https://doi.org/10.37284/eajenr.2.2.195

\section{Date Published: ABSTRACT}

14 August 2020 The degradation of any ecosystem services (ES) and the benefits human being enjoy from nature freely involve multifaceted processes such as those in built

Keywords: environment. The ecological security and multiple functions of the coastal zone

Dar es Salaam, Coastline, Service Value, Built Environment, Soil Erosion, Soil Fauna Dynamics, Carbon Stock. of Dar es Salaam is of paramount importance to the sustainability of its natural and anthropogenic systems. Therefore, permanent/temporary conversion of a piece of land for construction space provisions profoundly affects the functionality and connectedness of nature-anthropogenic ecosystem. This study quantified land use landcover changes from Landsat satellite imageries, then evaluated the changes using recognizable coefficients for ecosystem services values (ESV). Applying Geographical Information System (GIS) techniques, the impacts of built environment on ESV were analysed using land use landcover change (LULCC) transfer matrix, carbon stock dynamics and soil erosion influence on soil fauna. The results revealed expansive BE from 10.6 percent in 1995 to 22.8 percent in 2016. Loss of forest by 64.5 percent in the study period explained the declining total ESV by 56.1 percent and per capita recreation potential by 2.3 percent. Similarly, decreasing forest cover led to high carbon dioxide emission, notably, the $353.24 \mathrm{t} \mathrm{CO}_{2} \mathrm{ha}^{-1} \mathrm{yr}^{-1}$ in the period between 1995 and 2005. Furthermore, in 1995 bushland experienced high soil erosion while in 2016 built environment displayed a similar trend as the rest of the land use landcover (LULC) classes. From geospatial analysis, the southern area displayed significant vegetation cover change as compared to the built environment dominant in the northern section of Dar es Salaam coastline. Initiative to reducing built environment by 1 percent saves forest loss by 5.28 percent and carbon sequestration at a tune of $28.95 \mathrm{t} \mathrm{CO}_{2} \mathrm{ha}^{-1} \mathrm{yr}^{-1}$; hence improves ecological services values by 4.60 percent. 


\section{APA CITATION}

Manyama, M., Nahonyo, C., \& Hepelwa, A. (2020). Analysis of the Impact of Built Environment on Coastline Ecosystem Services and Values. East African Journal of Environment and Natural Resources, 2(2), 44-63. https://doi.org/10.37284/eajenr.2.2.195

\section{CHICAGO CITATION}

Manyama, Mkama, Cuthbert Nahonyo, and Aloyce Hepelwa. 2020. "Analysis of the Impact of Built Environment on Coastline Ecosystem Services and Values". East African Journal of Environment and Natural Resources 2 (2), $44-63$. https://doi.org/10.37284/eajenr.2.2.195.

\section{HARVARD CITATION}

Manyama, M., Nahonyo, C. and Hepelwa, A. (2020) "Analysis of the Impact of Built Environment on Coastline Ecosystem Services and Values", East African Journal of Environment and Natural Resources, 2(2), pp. 44-63. doi: 10.37284/eajenr.2.2.195.

\section{IEEE CITATION}

M. Manyama, C. Nahonyo, and A. Hepelwa, "Analysis of the Impact of Built Environment on Coastline Ecosystem Services and Values", EAJENR, vol. 2, no. 2, pp. 44-63, Jul 2020.

\section{MLA CITATION}

Manyama, Mkama, Cuthbert Nahonyo, and Aloyce Hepelwa. "Analysis of the Impact of Built Environment on Coastline Ecosystem Services and Values". East African Journal of Environment and Natural Resources, Vol. 2, no. 2, Jul 2020, pp. 4463, doi:10.37284/eajenr.2.2.195.

\section{INTRODUCTION}

The features, structures and facilities made, arranged, maintained and controlled by humans are rising globally (Kane \& Clark, 2019; Lobora et al., 2017; Seto et al., 2012). These urban places also referred to as built environment (BE) connote manmade spaces and places created or modified for various uses and users (Shahraki, 2017). Studies by Pinho and Lúcio (2017) reveal that the driving force on human thoughts, actions and experiences on $\mathrm{BE}$ is space value provision for recreation, workplaces and residence. According to Murdoch et al. (2018), burgeoning human population across global regions pressurizes the delivery of such space values. While $\mathrm{BE}$ assure the provision of exchange values, use values, image values, social values, cultural values and environmental values (Khademagha et al., 2016); the intended/unintended, direct/indirect, positive/negative both short and long-term impacts from LULCC of BE is a colossal challenge of our time (Aerts et al., 2014; Carmona, 2019). One of the greatest consequences of urban development is LULCC such as loss of vegetation cover, agricultural land and natural resource base meanwhile influencing environmental degradation and pollution (Halmy, Gessler, Hicke, \& Salem, 2015; Karki et al., 2018).
The nature benefits to human wellbeing is of paramount importance (van Heezik \& Brymer, 2018). Researchers Elmqvist et al. (2015) epitomize that presence of biodiversity in urban landscapes ensure humans with the availability of essential ES such as food provisioning, pollution reduction, climate regulation, carbon sequestration, and nutrient cycling. According to Butt et al. (2014) and Parris et al. (2018), BEs take, consume and sit permanently on a piece of land leading to landscape fragments and loss of ecological habitats. Such absence of ecological habitats connectedness reduces the landscape capacity to produce ES as well as access to ES by the ecological community (Cordingley et al., 2015). Aggressive construction activities and vegetation clearance cause soil erosion (Ligonja \& Shrestha, 2015), a key contributor to siltation into hydrological systems. Therefore, in high soil erosion risk zone (Panagos et al., 2012) like Dar es Salaam coast could be one among the drivers for hazardous, notably repeatedly flooding along Dar es Salaam coastline. Siltation and sedimentation in the Dar es Salaam Metropolitan make this coastal lowland and high soil erosion risk zone to face more hazardous events (Sakijege et al. 2012).

While microfauna is responsible for soil pores, loss of vegetation cover influence soil erosion events; such occurrences displace microfauna with negative effects on soil ecological system (Orgiazzi 
\& Panagos 2018; Shanshan et al., 2018). Study by Gashaw et al. (2014) content that loss of soil microfauna and vegetation cover impacts carbon cycle and stocks thus primary productivity. According to Senga (2014) and Zari (2014), landscape physical degradation including soil erosion disrupts the hydrological system and net biome productivity. Feedback loops on the aforementioned variables reduce nature resilience henceforth declining ES (Keller et al., 2018).

Recently, recognition, quantification and performance of ES in Anthropocene epoch has grown tremendously (Thomson and Newman, 2018; Zari, 2019), albeit ongoing global debate on urban biodiversity and its involvement in ES production and supply (Gómez-Baggethun \& Barton, 2013; Hurley \& Emery, 2018). Earliest work on ES studies by Costanza et al. (1997) set a stage on ES valuation proxies; today, literature reveals three approaches to ES valuation; willingness to pay (WTP), LULCC based methods and ecological process-benefit assessments (Yuan et al., 2019). According to Hepelwa (2013) and Schmidt et al. (2016) technological advancement in remote sensing (RS) and geographical information system (GIS) has efficiently improved LULCC based evaluation methods as compared to the others. Similarly, according to Xie et al. (2017), development of LULCC proxies for ES valuation delivered a useful approach to evaluating the impact of LULCC in various landscapes including urban centres. Lal (2015); Adhikari and Hartemink (2016) contend that GIS provides a platform to track and integrate ES, carbon stock and soil erosion data thus the supply of quantified statistics enable informed decision on green and inclusive cities, in particular, SDG 11.

Despite this, limited scholarly work has devoted to explore BE spatio-temporal changes and its effect on ES, notably along Dar es Salaam coastline.
Therefore, this study investigated the pattern of LULCC along Dar es Salaam coastline, with a focus on identifying evidence for urban ES changes. Application of geospatial approaches (Gombe et al. 2017; Mkalawa 2016) for monitoring LULCC using Landsat imageries enabled analysis of the built-up area, carbon stocks and soil erosion; hence quantifying impacts of such changes to soil fauna and ES values along Dar es Salaam coastline in Tanzania

\section{MATERIALS AND METHODS}

\section{Study Area}

Dar es Salaam lies between Latitude $6^{\circ} 3^{\prime} 43.09^{\prime \prime}$ to $7^{\circ} 10^{\prime} 47.35^{\prime \prime} \mathrm{S}$ and Longitude $39^{\circ} 6^{\prime} 36.37^{\prime \prime}$ to $39^{\circ}$ $33^{\prime}$ 5.66" E at 24 meters above sea level. The Metropolitan size is approximately $1800 \mathrm{~km}^{2}$ at $3: 1$ land: water coverage ratio along the southwestern coast of the Indian Ocean. This study concentrated on a section of $714.37 \mathrm{~km}^{2}$, which is 53 percent of the landmass of Dar es Salaam metropolis; the maximum inland distance was $16.6 \mathrm{~km}$ while the minimum was $3.3 \mathrm{~km}$. Dar es Salaam experience hot-humid climate greatly influenced by the northeast and southeast monsoon. The Metropolis receives an average annual rainfall of $172 \mathrm{~mm}$, has an average annual temperature of $29^{\circ} \mathrm{C}$ and humidity record of 96 percent in the morning and 67 percent in the afternoon. The coastal shrubs, miombo woodland, coastal swamps and mangrove trees represent the main natural vegetation cover type along the coastline. Governed in five districts of Kigamboni, Temeke, Ilala, Kinondoni and Ubungo. Dar es Salaam is the largest and most industrialized Metropolis in Tanzania. Its population has grown from 843,090 in 1978 to $5,465,420$ in 2016 with 94 percent being urbanites (Gombe et al. 2017; Mkalawa 2016). This study concentrated on the coastline of Dar es Salaam Metropolitan (Figure 1) 
East African Journal of Environment and Natural Resources, Volume 2, Issue 2, 2020 Article DOI: https://doi.org/10.37284/eajenr.2.2.195

Figure 1: Map of Dar es Salaam region showing the location of the study area

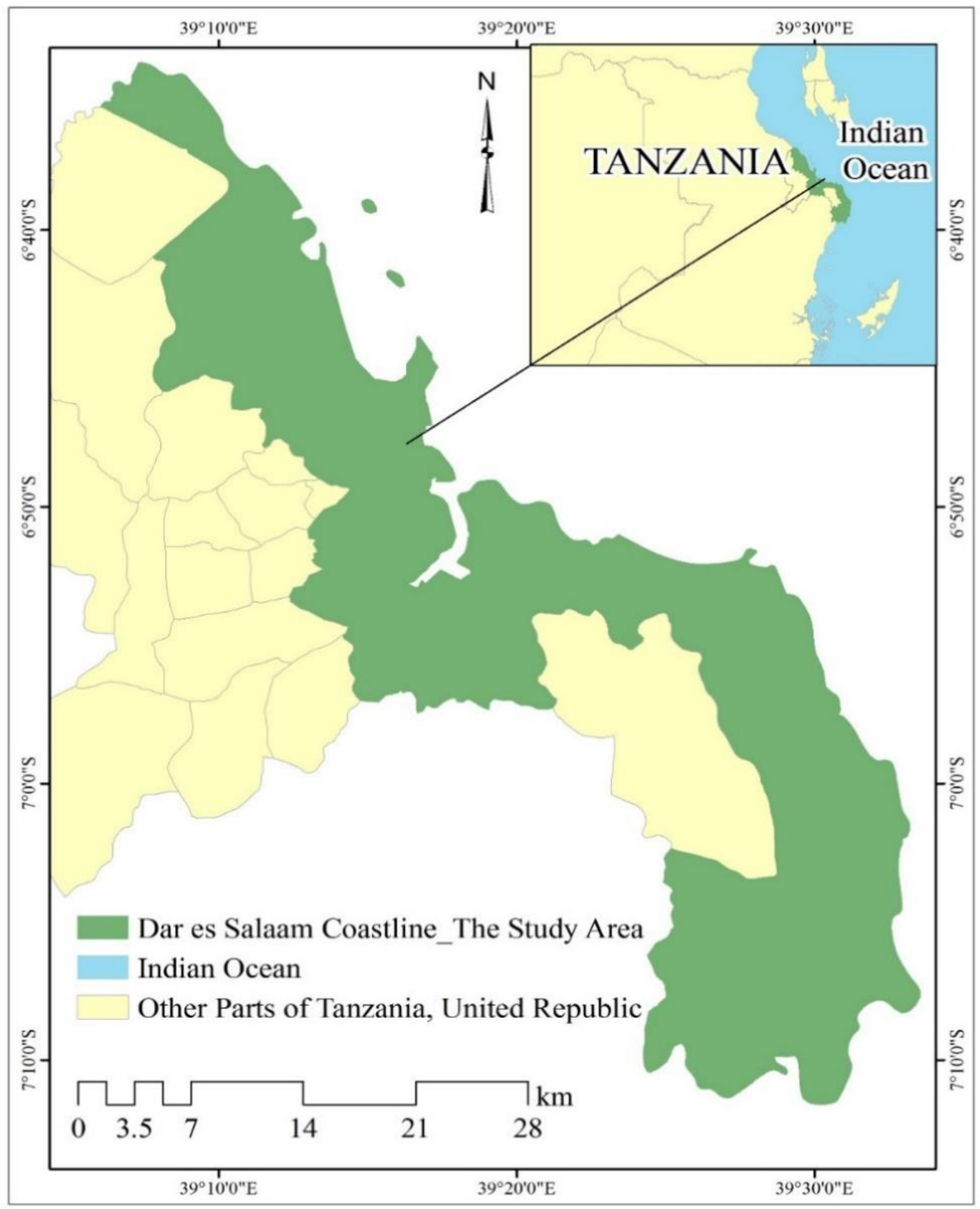




\section{Data Sources, LULC Classes and Accuracy Assessment}

Landsat Thematic Mapper (TM) images for June 1995 and 2005; and Landsat Operational Land Imager (OLI) for July 2016 were freely accessed and downloaded from United States Geological Survey (USGS) Earth Explorer (EE). Landsat scenes used were from path 166 row 65 for Dar es Salaam, Tanzania, with $30 \mathrm{~m}$ pixel resolutions and minimal cloud cover ( $<10$ percent). A series of processes involving data acquisition, data preprocessing, unsupervised and supervised classification, and post-classification comparison provided useful data. On the other hand, GPS based field survey supplied inputs for ground-truthing and accuracy assessment.

According to Iqbal and Khan 92014) as well as AlBilbisi (2019), simplicity of Landsat imagery interpretation depends on image pre-processing activities. In this study, image pre-processing underwent image registration and projection from UTM WGS 184_Zone_37N its downloadable format into UTM WGS 184_Zone_37S, the exact location of the study area. Thereafter, removal of top_of_atmosphere (TOA) reflectance activity and thereafter image enhancement procedure. Classification involved both unsupervised and supervised techniques. In unsupervised classification the image's final product is on the basis of LULC properties; execution of supervised classification using 35 training samples with corresponding spectral signatures (Awad et al. 2019; Diesing et al. 2016) as inputs to maximum likelihood algorithm in ArcGIS 10.3 provided seven LULC classes (Table 1) (URT, 2010). The methodological flow chart in ArcMap 10.3 is presented in Figure 2.

Table 1: Description of different LULC classes

\section{LULC Classes National Land Cover Description}

\begin{tabular}{ll}
\hline Forest & $\begin{array}{l}\text { An area of land with at least } 0.5 \text { ha, with a minimum tree cro } \\
\text { with tree reached a minimum height of } 3 \mathrm{~m} \text { or above at m } \\
\text { montane, lowland, mangrove and plantation forests, woodla }\end{array}$ \\
Bushland & $\begin{array}{l}\text { Bushland is predominantly comprised of plants that are mu } \\
\text { root base. It includes dense and open bushland }\end{array}$ \\
Grassland & $\begin{array}{l}\text { For the most part, grassland occurs in combination with eith } \\
\text { bushed component or with scattered subsistence cultivation }\end{array}$ \\
Agriculture & $\begin{array}{l}\text { Land actively used to grow agriculture crops including agrofor } \\
\text { crops, herbaceous crops and grain crops }\end{array}$ \\
Urban Area & City/Town settlement concentrations and its infrastructures \\
Bare Soil & Land which includes bare land and coastal sands \\
Water & Includes inland water and the Indian Ocean
\end{tabular}

Sources: URT 2010s

The LULC classes obtained underwent accuracy assessment (Rwanga \& Ndambuki, 2017). According to Susilo et al. (2018), any mismatch between reference data and image LULC classes indicates poor image classification. In estimating accuracy assessment, the study used the very recent image (2016) and 34 ground-truth reference data collected by global positioning system (GPS) tool (Rwanga and Ndambuki 2017; Susilo et al. 2018). 
Figure 2: Methodology flowchart for Landsat image LULC change detection

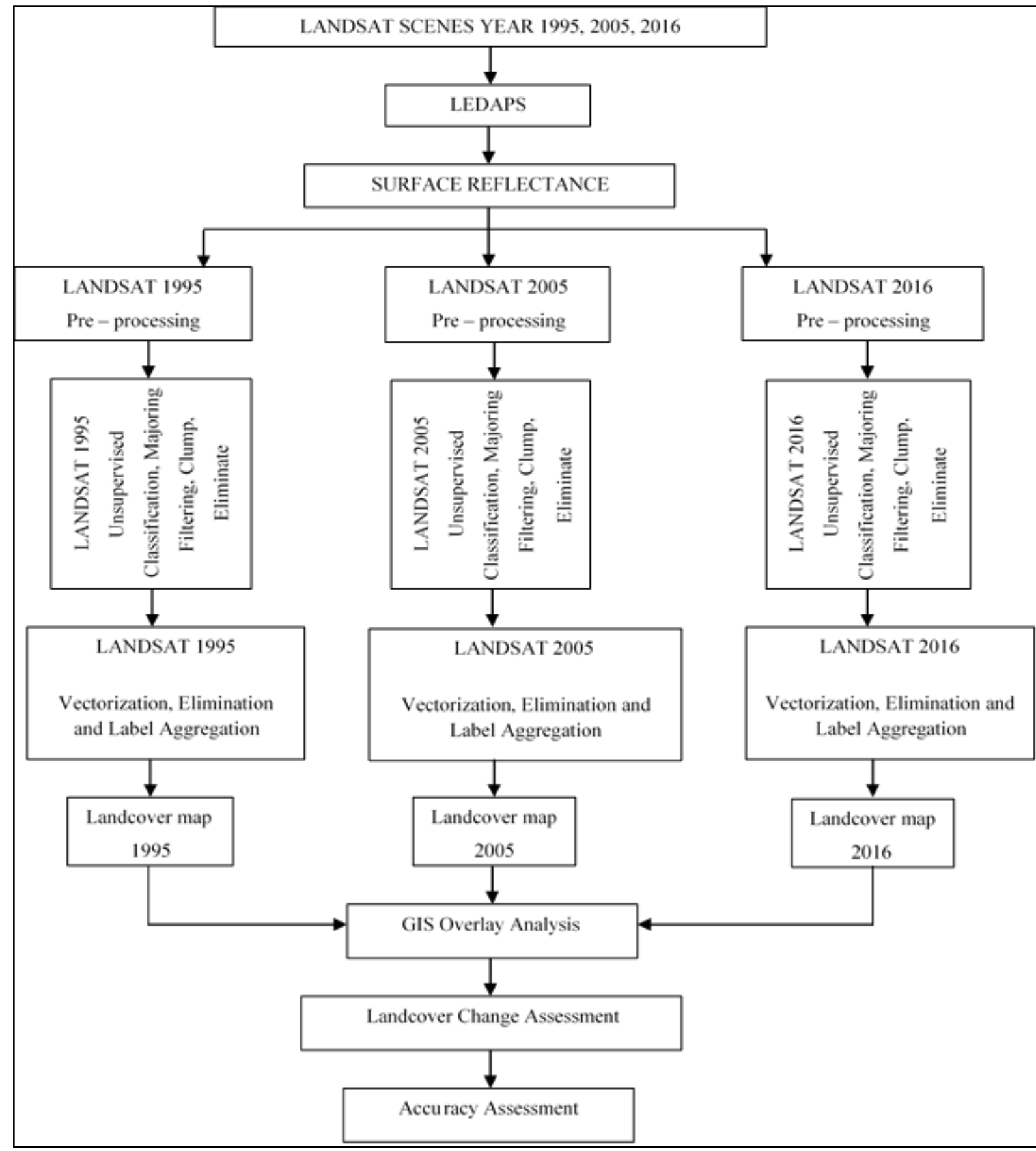

\section{Soil Erosion Estimation}

Understanding and quantification of detaching soil particles (soil erosion) and their relocation or displacement due to physical factors (Nyawade et al., 2019) is important in defining and setting strategies for resources conservation and management. According to Yesuph and Dagnew
(2019), an average soil erosion in tons per hectare per year ( $\left.\mathrm{t} \mathrm{ha} \mathrm{H}^{-1} \mathrm{yr}-1\right)$ depends on rainfall erosivity, soil erodibility, cover management, length and slope steepness and supporting practices. This study, using cross-tabulation analysis of RUSLE Model (Equation 1) and LULC changes polygon in ArcGIS v10.3 combined all the aforementioned 
factors to quantified soil erosion in each LULC classes (Koirala et al., 2019).

$A_{e}=R * K * L S * C_{p} * P$

Where; $\mathrm{A}_{\mathrm{e}}$ : Average soil erosion (in tons per hectares per year); R: Rainfall erosivity factor (MJ mm ha-1); K: Soil erodibility factor (t ha-1 yr-1)/ (ha MJ mm); $\mathrm{C}_{\mathrm{p}}$ : Cover management factor (dimensionless); LS: Length and slope steepness factor (dimensionless); Support practice factor (dimensionless)

\section{Loss of Soil Fauna}

Globally, the effect of urbanization on the natural landscape is noticeable (You \& Yang, 2017).
Increasing soil erosion and urban runoff have been reported to significantly contribute to the loss of biodiversity (Ligonja \& Shrestha, 2015; Orgiazzi \& Panagos, 2018; Shanshan et al., 2018). The reciprocal relationship between soil erosion and biodiversity is a natural phenomenon (Olson et al., 2016; Orgiazzi \& Panagos, 2018), nevertheless, studies (Hui et al. 2019; Kane and Clark 2019; Zari 2014) depicts increasing urban run-off due to expansive built environment that destructs soilbiodiversity linkage. In this study, the soil erosion data from Eq. 1 and soil erosion lost/displaced fauna species equivalencies in Table 2 (Orgiazzi \& Panagos, 2018) were used to quantify lost/displaced soil fauna species.

\section{Table 2: Approximated loss equivalencies for soil fauna species}

\begin{tabular}{ll}
\hline Species categories (lost) & $\begin{array}{l}\text { Estimated average species lost/displaced by } \\
\text { runoff of } \mathbf{1} \text { ton (t) of soil per hectare (ha)/year } \\
(\mathbf{y r} .)\end{array}$ \\
\hline Prokaryotes (cells) & $8.00 \times 10^{15}$ \\
Fungi (metres of hyphae) & $1.00 \times 10^{8}$ \\
Arbuscular mycorrhizal fungi (metres of hyphae) & $6.40 \times 10^{7}$ \\
Protists (individuals) & $6.70 \times 10^{12}$ \\
Nematodes (individuals) & $3.07 \times 10^{12}$ \\
Enchytraeids (individuals) & $1.44 \mathrm{E} \times 10^{6}$ \\
Collembola (Individuals) & $2.00 \times 10^{6}$ \\
Mites (Oribatida - individuals) & $3.67 \times 10^{6}$ \\
Isopoda (Individuals) & $6.67 \times 10^{2}$ \\
Earthworms (Oligochaeta individuals) & $2.00 \times 10^{4}$ \\
\hline Source: (Orgiazz \& Panags, 2018)
\end{tabular}

Source: (Orgiazzi \& Panagos, 2018)

\section{Carbon Stock Estimation}

Studies by Bindu et al. (2018) and Ekoungoulou et al. (2015) clearly documents the carbon stock dynamics with respect to LULC changes. The interlacing relationship between rapidly expanding $\mathrm{BE}$ and climate change scenarios calls for concrete data on LULC - carbon interactions (Mannan et al., 2019). In view of this, the study estimated AGC from $\mathrm{AGB}$ and BGC from BGB. Then applying NAFORMA (Malimbwi \& Zahabu, 2014), developed carbon proxy equivalence as $59.5 \mathrm{t} / \mathrm{ha}$ for $\mathrm{AGB}$ and $18.2 \mathrm{t} / \mathrm{ha}$ for $\mathrm{BGB}$, the relation between AGB and BGB is provided by Equation 2 . Conversion of GB into GC is by default factor (Equation 3). Recent estimate (Alavaisha \&
Mangora, 2016) of mangrove-based carbon stocks along Dar es Salaam coastline provide an equivalence of $26.18 \mathrm{t} \mathrm{C} / \mathrm{ha}$. The remote sensing and GIS extracted LULC changes data of the study area providing useful input for the computation of carbon stocks dynamics along the coastline.

$B G B=0.25 * A G B$

$G C=0.47 * G B$

Where: AGB: Above ground biomass (t/ha); BGB: Below ground biomass (t/ha); GB: Ground biomass i.e. AGB and BGB (t/ha); GC: Ground carbon i.e. Carbon stocks (t/ha). 


\section{Ecosystem Services Values Function (ESVf) Estimation}

ESVf measures the capacity of an ecosystem to produce and supply ES to landscape habitats (Rieb et al., 2017); and that its understanding is a vital requirement across a range of stakeholders with fatal decision in green cities, sustainability and climate changes initiatives (Bidegain et al., 2019). That being the case, the study extracted the quantity of each LULC classes converted into built environment, hence treated them as lost ES; thereafter their monetary values were obtained through the application of ES values equivalences from (Costanza et al., 1997). Despite several existing methods for ES valuation (Neugarten et al., 2018), the ESVf in Table 3, which is an extract from (Costanza et al., 1997) and (Yuan et al., 2019) has been instrumental in understanding the cost of LULC conversion. Equation 4 provides both the relation between ESVf and LULC data as well as the approach to compute the monetary value of the lost ES from 1995 to 2016;

$E S V_{f}=\sum A_{k} \times V C_{f k}$

Where: $E S V_{f}$ is the ecosystem service values function; $A_{k}$ is the LULC area size in hectares; $V C_{f k}$ is the coefficient of ecosystem service function (US \$ ha-1 yr-1) for LULC class k.

Table 3: Coefficient of ESVf in US $\$ \mathrm{ha}^{-1} \mathrm{yr}^{-1}$

\begin{tabular}{llllll}
\hline Category & Forest & Grassland & Farmland & River/lake & $\begin{array}{l}\text { Construction } \\
\text { Land }\end{array}$ \\
\hline Food production & 0.80 & 1.24 & 1.00 & 0.76 & 0.09 \\
Hydrological regulation & 0.09 & 0.06 & 0.00 & 0.14 & 0.04 \\
Waste treatment & 1.61 & 1.61 & 0.00 & 12.31 & 0.09 \\
Soil formation and conservation & 8.65 & 0.56 & 0.00 & 0.00 & 0.01 \\
Biodiversity maintenance & 0.33 & 0.89 & 0.70 & 0.00 & 0.05 \\
Providing aesthetic value & 1.26 & 0.04 & 0.00 & 4.26 & 0.11 \\
\hline
\end{tabular}

\section{RESULTS AND DISCUSSION}

\section{LULC Change Dynamics}

Recently, the use of LULC change approach in monitoring and evaluating the impact of anthropogenic activities from Landsat satellite imageries have proved to provide useful environmental data, particularly, on the past time (Kukulska-Kozieł et al., 2019). The ArcGIS unsupervised and supervised Landsat classification procedures (Figure 2) provided the results in Figure 3, showing that agriculture and built-up landscape increased significantly between 1995 to 2016; while vegetation cover, particularly in the southern parts of the coastline (Figure 4), experienced a declining trend. In the same period, the annual rate of change in grassland and forest cover displayed a high negative value than the rest of the LULC classes (Table 4). Such value indicates loss of green spaces along Dar es Salaam coastline metropolitan, which according to (Mkalawa, 2016; Mkalawa \& Haixiao, 2014) increasing built environment and decreasing vegetation cover revealed is linked to the coincidence of population growth, economic growth and demand for infrastructures in Dar es Salaam. It is important to observe recommended plot coverage and roadside strips if green cover is to be maintained in the human being dominated environment such as Dar es Salaam. 
East African Journal of Environment and Natural Resources, Volume 2, Issue 2, 2020

Article DOI: https://doi.org/10.37284/eajenr.2.2.195

Table 4: Annual average rate of LULC change at Dar es Salaam coastline

\begin{tabular}{lllllll}
\hline LULC Class & $\mathbf{1 9 9 5}$ & $\mathbf{2 0 0 5}$ & $\mathbf{2 0 1 6}$ & $\mathbf{1 9 9 5} \mathbf{- 2 0 0 5}$ & $\mathbf{2 0 0 5} \mathbf{- 2 0 1 6}$ & $\mathbf{1 9 9 5} \mathbf{- 2 0 1 6}$ \\
\hline AG: Agriculture (\%) & 1.5 & 1.9 & 2.6 & 0.5 & 0.9 & 1.1 \\
BS: Bare Soil (\%) & 0.0 & 0.1 & 0.1 & 0.1 & 0.0 & 0.1 \\
BU: Bushland (\%) & 2.3 & 3.1 & 2.5 & 0.8 & -0.3 & 0.2 \\
FO: Forest (\%) & 2.2 & 0.9 & 0.7 & -1.2 & -0.2 & -1.5 \\
GL: Grassland (\%) & 2.3 & 2.2 & 0.5 & -0.1 & -1.5 & -1.8 \\
BE: Urban Area (\%) & 1.2 & 1.5 & 2.6 & 0.3 & 1.2 & 1.4 \\
WA: Water (\%) & 0.5 & 0.2 & 0.2 & -0.3 & 0.0 & -03 \\
\hline
\end{tabular}

As a product of urbanization, BE promotes various massive infrastructure development to meet the demands of the growing number of urbanites. This expanding BEs take, consume and seat permanently on a piece of land, thus loss of habitats and ecological species due to fragmentation, isolation and extinction (Aerts et al., 2014; Zheng et al., 2017). Decreasing ecological species affect the ecosystem components, functions and structure hence qualities and quantities of ESS produced in respective landscapes. Such reduced ESS activates more resources extraction beyond the landscape's boundaries; a situation that leads to further impacts associated with expanding agricultural landscape and BE (Table 4 \& Table 5). The established requirement for food production to feed the urbanites, energy (firewood and charcoal) (Malimbwi \& Zahabu, 2014; URT, 2010) and raw materials for infrastructure development, are the driving forces for such expansion.

Figure 3: LULC class distribution in the study area from 1995 to 2016

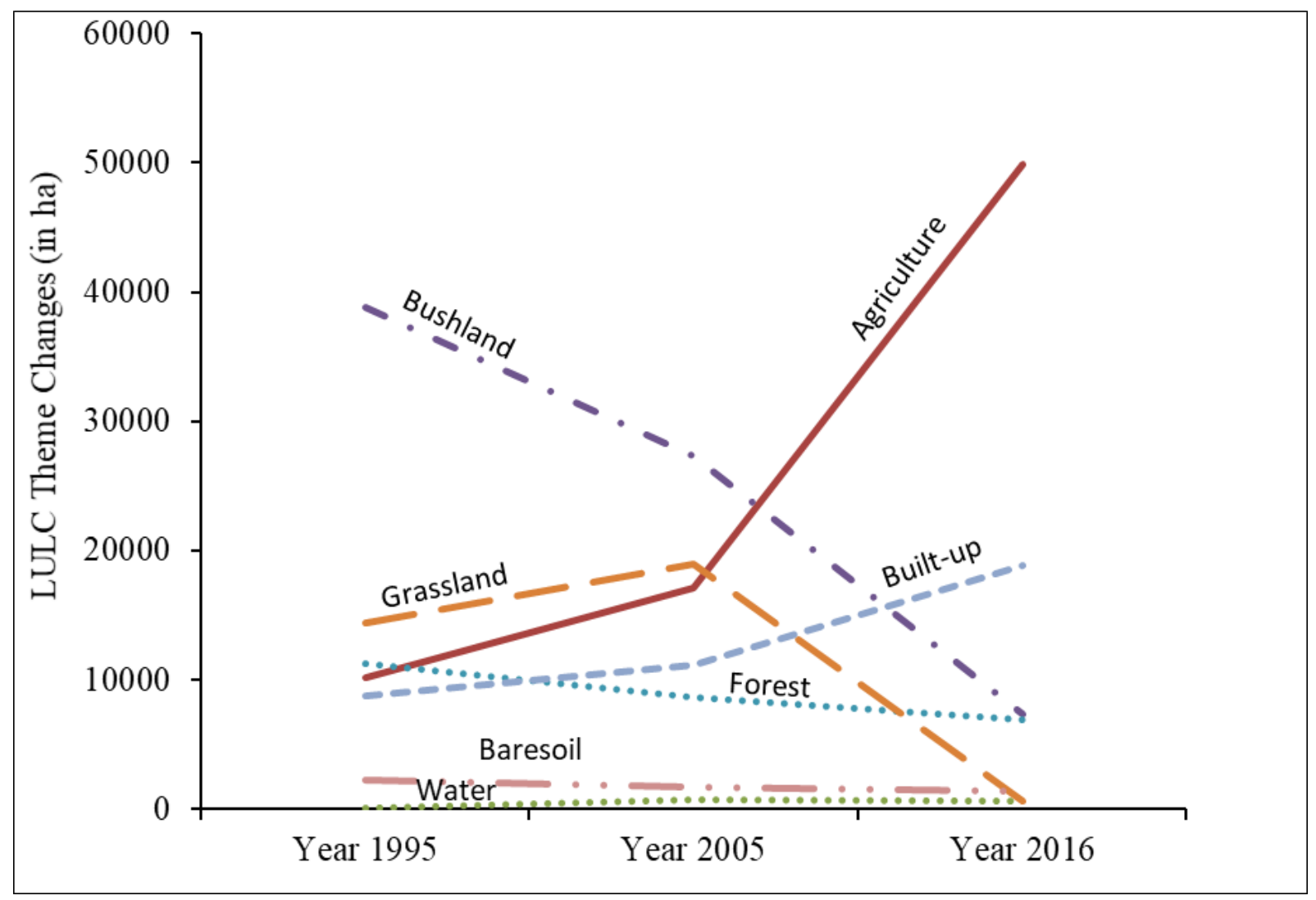


Figure 4: Dar es Salaam coastline LULC changes from 1995 to 2016

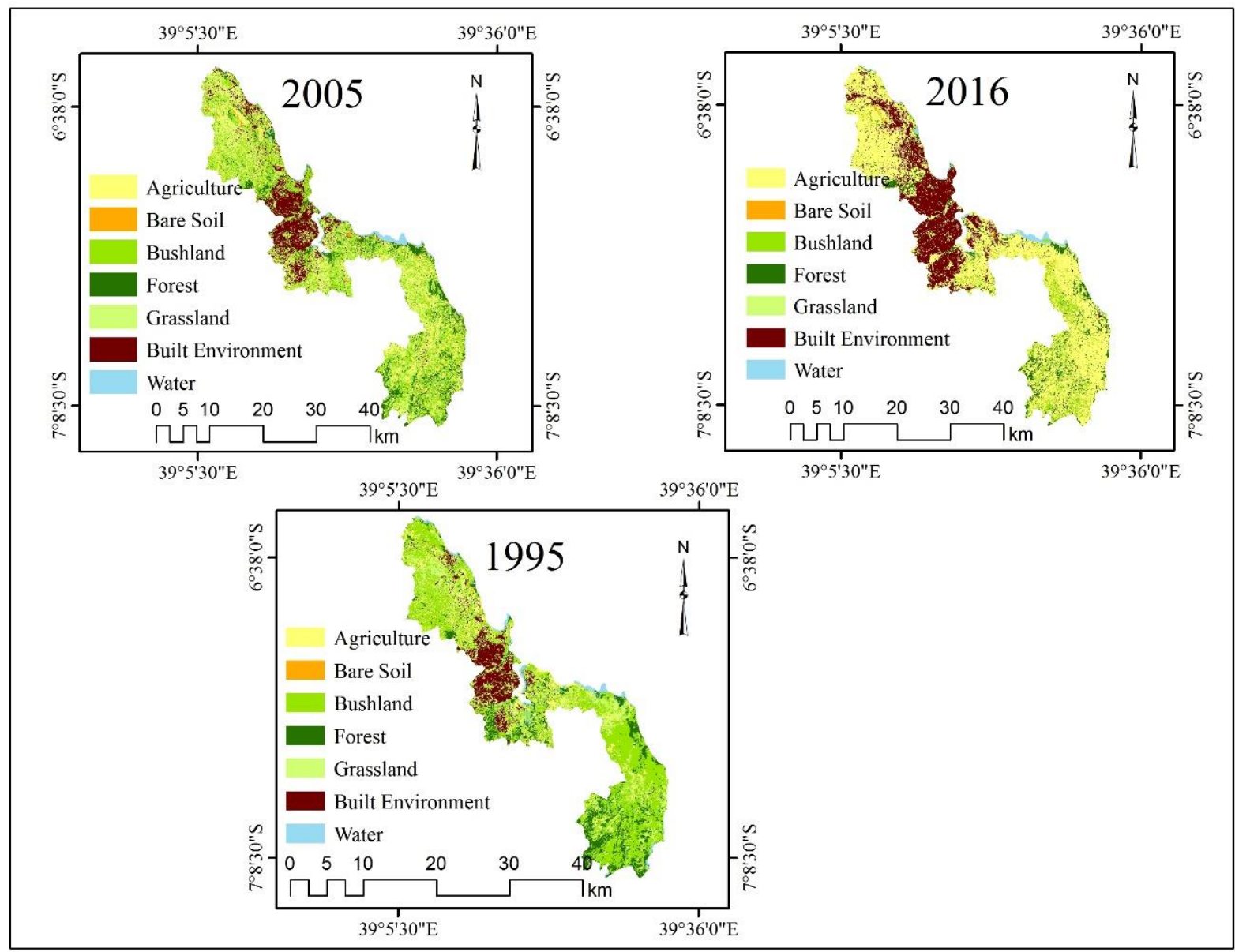

\section{Level of Recreation Potentials}

Increasing population in the study area from $2,316,071$ in 1995 to $2,568,015$ in 2005 and $3,252,317$ in 2016 influenced vegetation cover changes (forest, bushland and grassland) decline from 61,873 hectares in 1995 to 54,274 in 2005 and 14,518 in 2016. In these periods, forest cover contributed a significant share to other LULC classes, in particular, conversion into the built-up environment (Table 5). The reciprocal relationship between increased population and decreasing vegetation cover (Figure 5) displayed decreasing per capita recreation potential. Statistically, the urbanites level of enjoyment of vegetation-based ES appear to be decreasing considerably $\left(\mathrm{R}^{2}=\right.$ 0.94). The impact of poor recreation and aesthetic potentials in the anthropogenic environment is associated with increasing low social engagement, ineffective physical activities and low reasoning capacity and fear, notably in childhood (de Sa \& Ardern, 2014).

Table 5: LULC conversion into BE at Dar es Salaam coastline from 1995 - 2016

\begin{tabular}{llllllll}
\hline LULC classes & AG & BS & BU & FO & GL & BE & WA \\
\hline $1995-2005$ & 637.83 & 7.56 & 676.8 & 608.85 & 23.67 & 0.00 & 260.91 \\
$2005-2016$ & 2825.01 & 52.02 & 58.23 & 4601.16 & 4194.9 & 0.00 & 260.91 \\
\hline
\end{tabular}


Figure 5: Trend of recreation potential along Dar es Salaam coastline

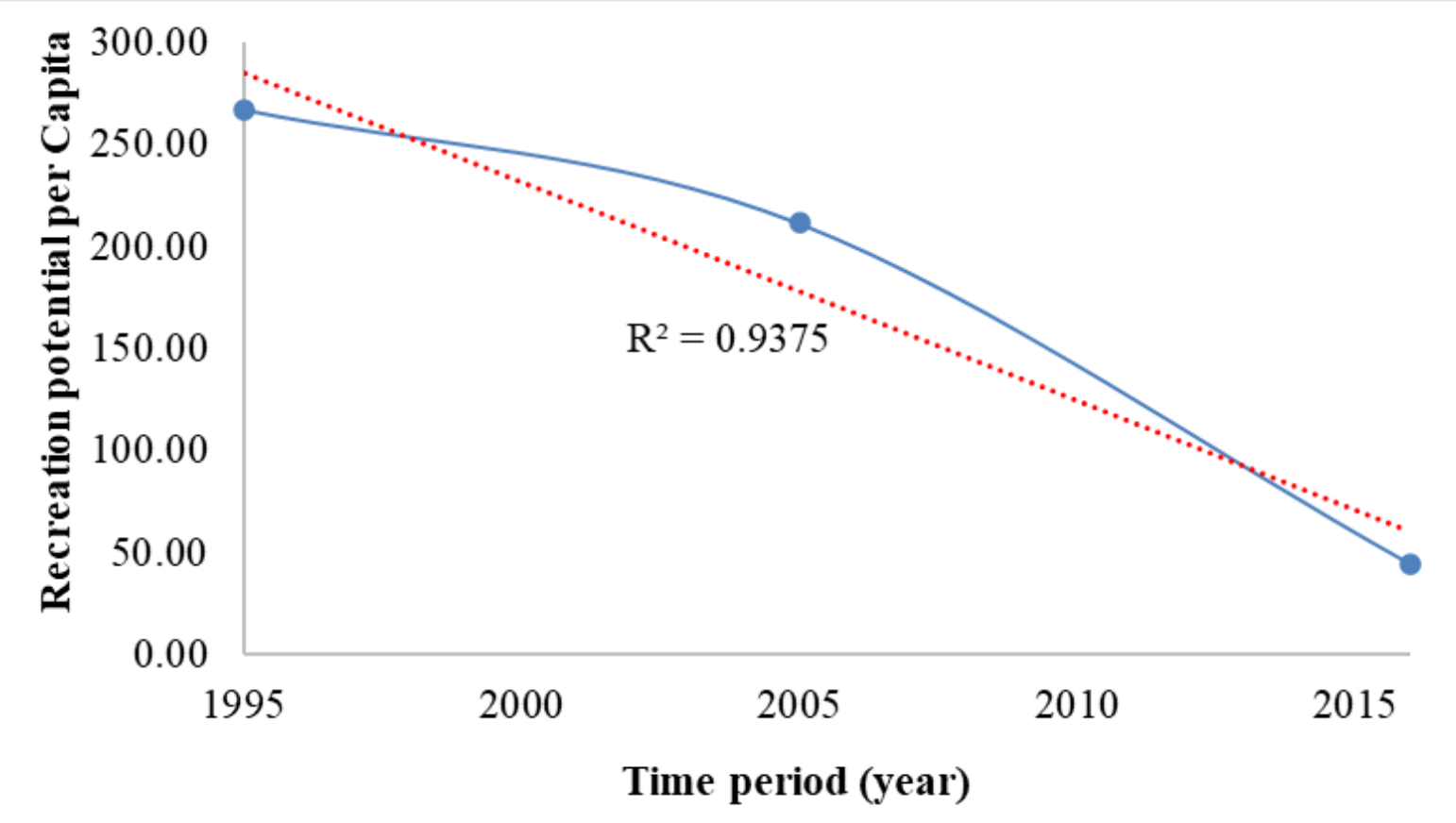

\section{Estimation of Carbon Stock}

Analysis of LULC carbon stock using (Malimbwi \& Zahabu, 2014; URT, 2010) carbon estimation equivalence, displayed a declining trend to both above ground carbon (AGC) and below ground carbon $(\mathrm{BGC})\left(\mathrm{R}^{2}=0.82\right)$, for forest covers (Figure 6). Applying a factor of 3.6667 in relating carbon and carbon dioxide, the study quantified the amount of carbon dioxide emission (
Table 6). Decreasing vegetation cover interferes carbon cycle and other biogeochemical cycles (Butt et al., 2014; Parris et al., 2018), leading to carbon dioxide in the biosphere; continual rising of this greenhouse gases (GHGs) (Table 6) contributes to climate change incidences at Dar es Salaam coastline. Furthermore, expansion of BE linked impervious surfaces disrupts hydrological cycles hence local microclimate dynamics. According to (Parris, 2016; Watkiss et al., 2011) climate change impacts is profoundly leading to increased flooding events, Dar es Salaam every rain season risk events.

Table 6: Relationship between Carbon stock and carbon dioxide

\begin{tabular}{|c|c|c|c|c|c|c|}
\hline \multirow[t]{2}{*}{ Carbon stock (t C ha-1 yr-1) } & \multirow[b]{2}{*}{$\begin{array}{l}\text { Time } \\
\text { period }\end{array}$} & \multicolumn{5}{|c|}{$\begin{array}{l}\text { Carbon dioxide }\left(\mathrm{CO}_{2}\right) \text { emission } \\
\text { (t } \mathrm{CO}_{2} \text { ha-1 yr-1) }\end{array}$} \\
\hline & & 1995 & 2005 & 2016 & 1995 - 2005 & $2005-2016$ \\
\hline & Mangrove & 119.4 & 93.4 & 55.6 & 95.6 & 138.3 \\
\hline Other Vegetation Cover & AGC & 193.7 & 137.5 & 129.9 & 206.1 & 28.1 \\
\hline Cover & BGC & 48.4 & 34.4 & 32.5 & 51.5 & 7.0 \\
\hline
\end{tabular}


Figure 6: Trend of carbon stock along the coastline of Dar es Salaam coastline

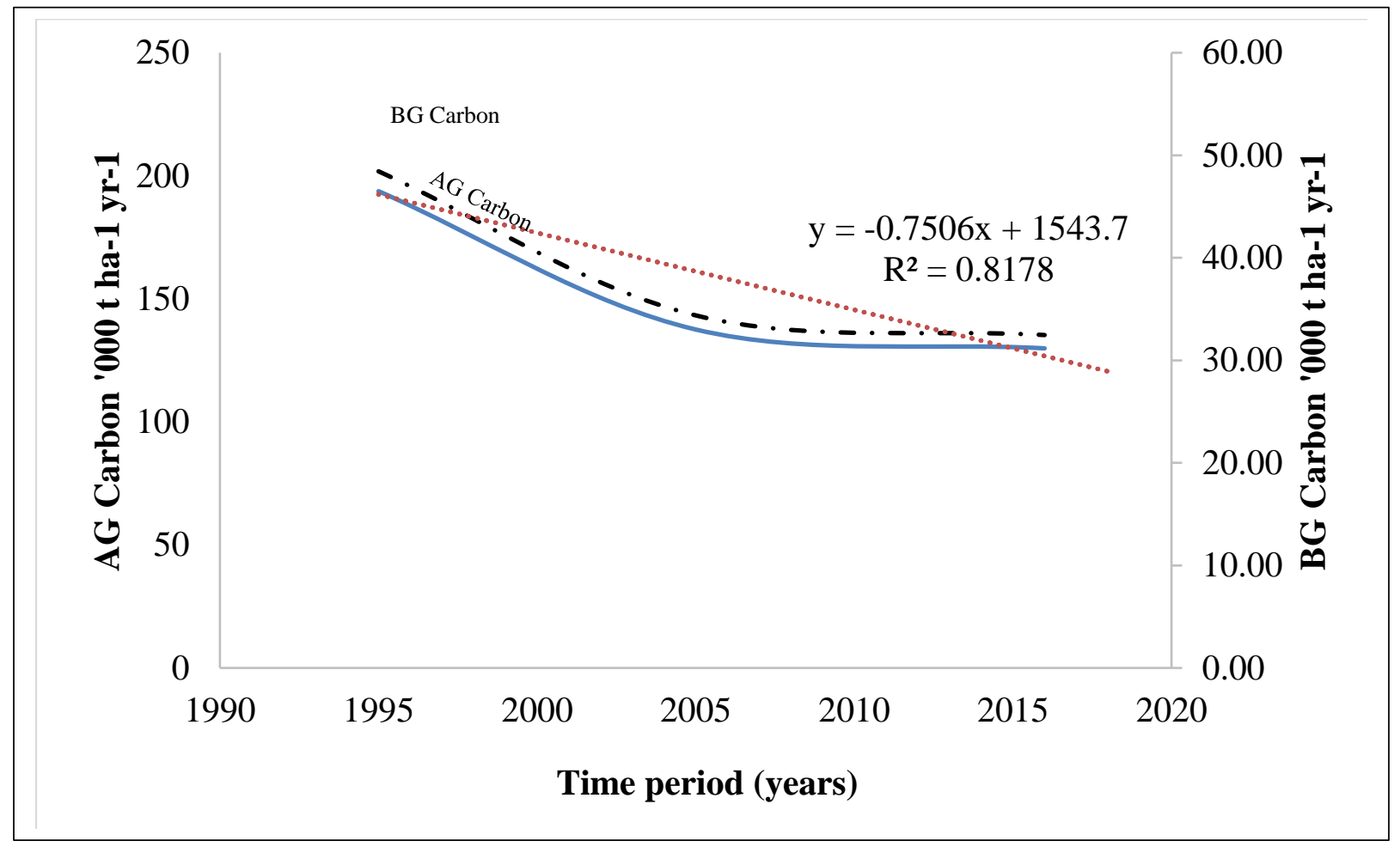

\section{Soil Erosion Modelling}

From Figure 7, the analysis provides that in 1995, bushland had the highest soil erosion while in 2016 agriculture and built-up landscape displayed highest soil erosion. Studies show that expanding $\mathrm{BE}$ increases impervious surface (Baker et al. 2019), a blockage structure between lithosphere, atmosphere, (Costanza et al., 1997) hydrosphere and geosphere thus destroying soil porosity, structure, texture, density as well as functions of biogeochemical cycles. Limited porosity, water and soil aeration flow in BE influence soil chemical and physical properties hence ES production and supply dynamics. Meanwhile, expanding BE insinuates huge urban-runoff abetting soil erosion, biodiversity loss and pollution of hydrological resources. The three aforementioned factors contribute significantly to poor quality and quantity, and or loss of ES in the respective landscape. High soil erosion in 2016 as compared to 1995 is explained by various construction activities in Dar es Salaam central business district (DCBD). In this period, the DCBD experienced commercial buildings skyrocketing and urban road infrastructures, notably, Dar es Salaam Bus Rapid Transit (DART) project (Rizzo 2014; de Sa and Ardern 2014). Therefore, extraction of construction materials as well as urban-runoff is likely to be the cause of such dynamics in soil erosion quantities. 
Figure 7: Dar es Salaam coastline soil erosion across LULC classes

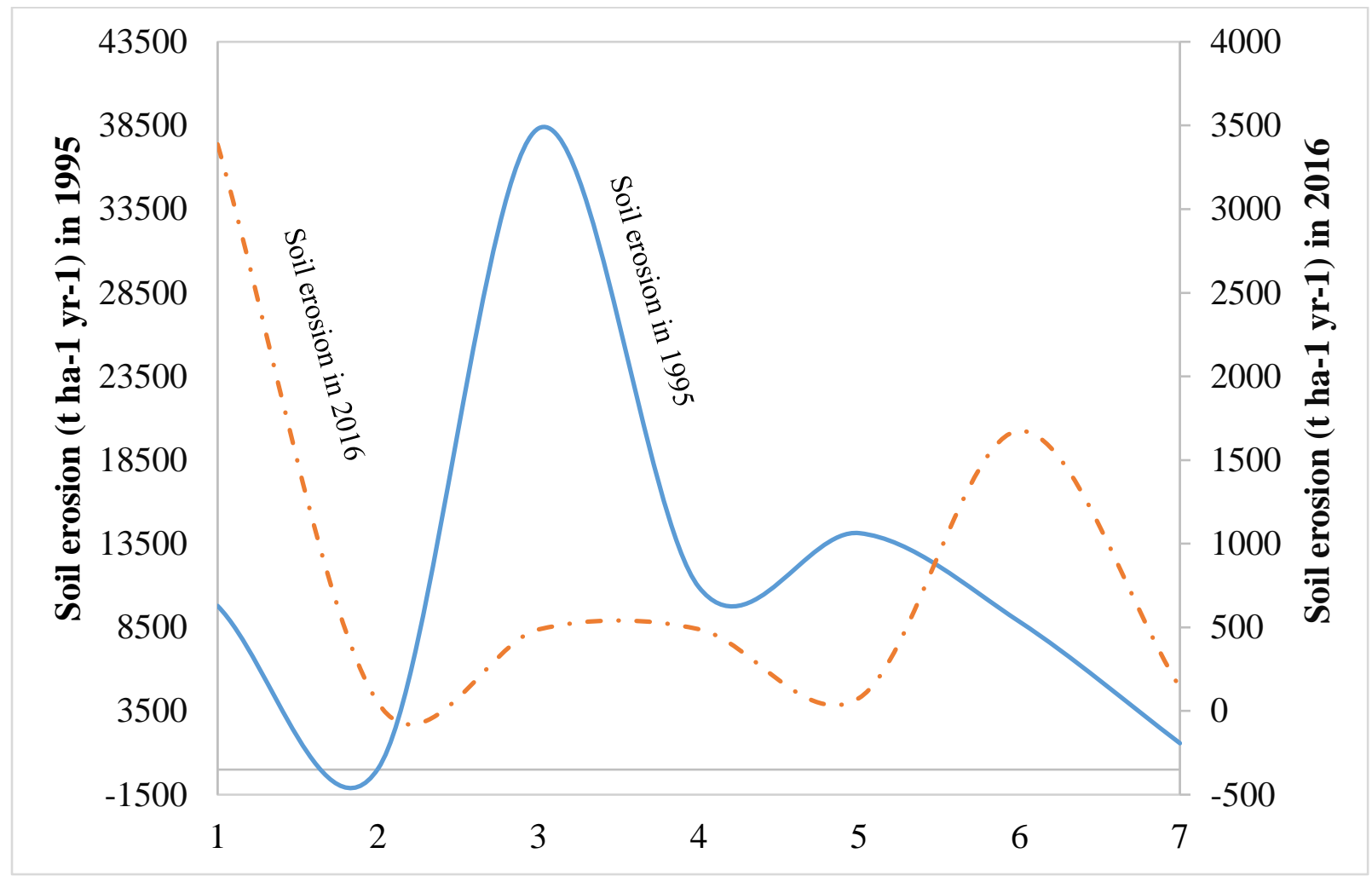

Note: 1: Agriculture, 2: Bare soil, 3: Bushland, 4: Forest, 5: Grassland, 6: Built Environment, 7: Water

\section{Soil Fauna Lost/Displaced by Soil Erosion}

Quantification of soil fauna displaced/lost by soil erosion (Table 7) involved the use of soil fauna coefficients (Orgiazzi \& Panagos, 2018). Results show that soil fauna loss increased significantly in Nematodes (21.7 percent), Earthworms (18.2 percent) and 17.9 percent in Mites, Collembola and Enchytraeids respectively. The diverse and numerous plant and soil microfauna are central to soil ecosystem natural settings, in which the microbial activities are responsible for soil physical, chemical and biological properties (Jacoby et al., 2017). Their decomposition and nitrogen-fixing characteristics account significantly for energy and nutrient circling. Thus, loss/displacement of soil fauna due to $\mathrm{BE}$ processes, activities and expansion is indirectly or directly interfering soil formation and properties. In the context of ES production and supply, loss/displacement of soil fauna by soil erosion interferes with the functioning of biogeochemical cycles, water infiltration and aeration, soil formation and properties and atmospheric gas regulations. Studies (Lal, 2014, 2015; Orgiazzi \& Panagos, 2018) epitomizes that the interaction between soil biodiversity and soil erosion are complex interlinked and bidirectional and that the magnitude of negative effect to each other lies in the presence of anthropogenic issue. 
East African Journal of Environment and Natural Resources, Volume 2, Issue 2, 2020

Article DOI: https://doi.org/10.37284/eajenr.2.2.195

Table 7: Estimate fauna species lost/displaced due to soil erosion

\begin{tabular}{lllll}
\hline Species categories & Year 1995 & Year 2016 & $\mathbf{1 9 9 5}-\mathbf{2 0 1 6}$ & $(\boldsymbol{\%})$ change \\
\hline Prokaryotes (cells) & $7.10 \times 10^{18}$ & $1.34 \times 10^{18}$ & $5.76 \times 10^{18}$ & 0.98 \\
Fungi (metres of hyphae) & $8.84 \times 10^{11}$ & $1.70 \times 10^{11}$ & $7.14 \times 10^{11}$ & 0.81 \\
Arbuscular mycorrhizal fungi & $5.60 \times 10^{11}$ & $1.07 \times 10^{09}$ & $5.59 \times 10^{11}$ & 1.00 \\
(metres of hyphae) & $5.90 \times 10^{14}$ & $1.12 \times 10^{13}$ & $5.79 \times 10^{14}$ & 0.98 \\
Protists (individuals) & $2.71 \times 10^{14}$ & $6.15 \times 10^{15}$ & $-5.88 \times 10^{15}$ & -21.69 \\
Nematodes (individuals) & $1.27 \times 10^{8}$ & $2.40 \times 10^{09}$ & $-2.27 \times 10^{9}$ & -17.90 \\
Enchytraeids (individuals) & $1.77 \times 10^{8}$ & $3.35 \times 10^{9}$ & $-3.17 \times 10^{9}$ & -17.93 \\
Collembola (Individuals) & $3.24 \times 10^{8}$ & $6.15 \times 10^{9}$ & $-5.83 \times 10^{9}$ & -17.98 \\
Mites (Oribatida - individuals) & $5.90 \times 10^{6}$ & $1.10 \times 10^{6}$ & $4.80 \times 10^{6}$ & 0.81 \\
Isopoda (Individuals) & $1.77 \times 10^{6}$ & $3.40 \times 10^{7}$ & $-3.22 \times 10^{7}$ & -18.21 \\
Earthworms (Oligochaeta individuals) & & & & \\
\hline
\end{tabular}

ESVs Changes and the Cost of LULC Conversion

ESVs displayed general annual decline from US $\$ 55.4$ per hectare in 1995 to US $\$ 24.25$ per hectare in 2016, signifying a 56.2 percent decline respectively. While the values of forest dropped significantly, tremendous value increase observed in bushland and agricultural land (Table 8). During the study period, the value of ESVf changed too (Figure 8 (a) - (d)). Analysis of ESVf on LULC converted into BE displayed significant changes in the study area (Table 9).

Table 8: ESVs changes in Dar es Salaam coastline coastline

\begin{tabular}{lllll}
\hline \multirow{2}{*}{ LULC_Classes } & Value coefficient (VC) in US \$ha-1yr- & \multicolumn{3}{l}{ Total ESV (US \$ha-1yr-1) } \\
\cline { 3 - 5 } & $\mathbf{1}$ & $\mathbf{E S V}_{\mathbf{1 9 9 5}}$ & $\mathbf{E S V}_{\mathbf{2 0 0 5}}$ & $\mathbf{E S V}_{\mathbf{2 0 1 6}}$ \\
\hline Agriculture & 92 & $1,002,248$ & $1,308,424$ & $1,961,348$ \\
Bush land & 232 & $3,864,888$ & $5,220,000$ & $4,595,920$ \\
Forest & 969 & $15,282,099$ & $6,693,852$ & $5,385,702$ \\
Grassland & 232 & $3,943,536$ & $3,693,440$ & 864,200 \\
Water & 8498 & $31,306,632$ & $14,174,664$ & $11,446,806$ \\
\hline Total ESV & $\mathbf{1 0 0 2 3}$ & $\mathbf{5 5 , 3 9 9 , 4 0 3}$ & $\mathbf{3 1 , 0 9 0 , 3 8 0}$ & $\mathbf{2 4 , 2 5 3 , 9 7 6}$ \\
\hline
\end{tabular}


Figure 8: Time-value trends of selected ESVf along Dar es Salaam coastline

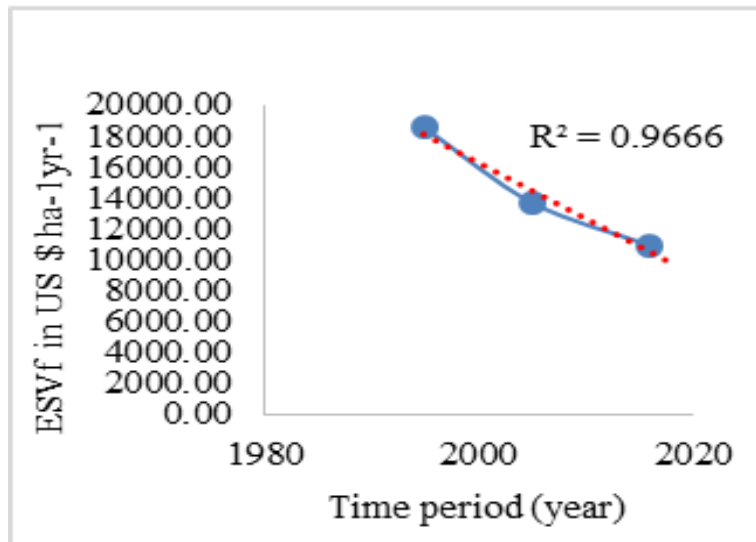

(a) Waste treatment in forest

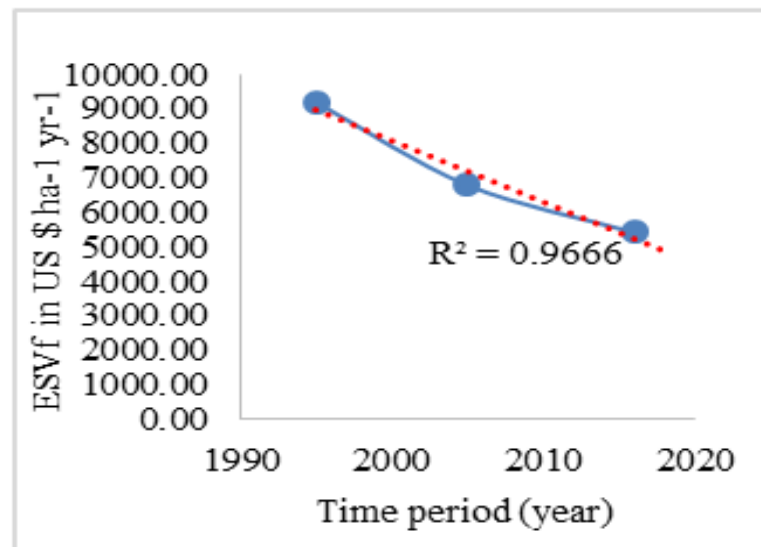

(c) Food production in forest

Converting natural land into anthropogenic space, reduce biodiversity habitats hence compromising ES production and supply. This research findings coincide with research finds from other scholars, that declining ESV is aggravated by human population growth, expanding built environment due to infrastructure development, and agricultural

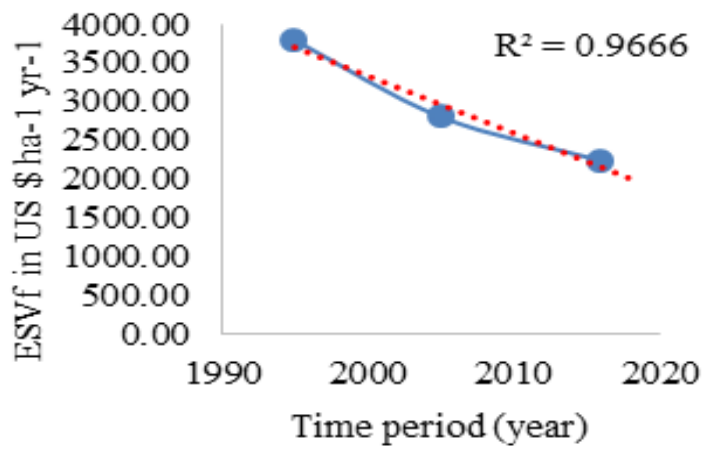

(b) Biodiversity in forest

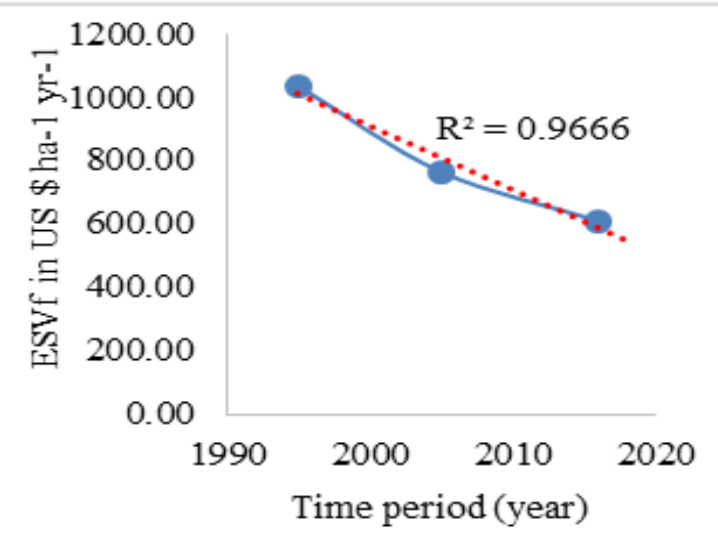

(d) Hydrological regulation in forest

landscape expansion due to high nutrient demand by the urbanites (Parris 2016; Wang et al. 2019; Zari 2018). Furthermore, compromised ESVf make urban landscape more vulnerable to wastes and pollutions; disconnected landscape reduces habitat resilience to local and transboundary environmental challenges.

Table 9: The cost of LULC conversion along Dar es Salaam coastline

\begin{tabular}{lllll}
\hline \multirow{2}{*}{ Category } & \multicolumn{2}{l}{ Before conversion into BE } & \multicolumn{2}{c}{ After conversion into BE } \\
& $\mathbf{1 9 9 5}-\mathbf{2 0 0 5}$ & $\mathbf{2 0 0 5} \mathbf{- 2 0 1 6}$ & $\mathbf{1 9 9 5} \mathbf{2 0 0 5}$ & $\mathbf{2 0 0 5}-\mathbf{2 0 1 6}$ \\
\hline Food production & 2042.9 & 11965.3 & 199.4 & 1079.3 \\
Hydrological regulation & 143.5 & 706.7 & 177.3 & 959.4 \\
Waste treatment & 5319.8 & 17467.2 & 199.4 & 1079.3 \\
Soil formation & 8395.0 & 42400.4 & 22.2 & 119.9 \\
Biodiversity maintenance & 1081.3 & 7264.9 & 110.8 & 599.6 \\
Aesthetics value & 2319.5 & 7114.6 & 243.7 & 1319.2 \\
\hline
\end{tabular}




\section{CONCLUSION}

In this work, LULC data and GIS technological application enabled assessment of the impact of the built environment (urban area) on ESV changes along Dar es Salaam coastline from 1995 to 2016. The BE expanded from 10.6 percent in 1995 to 22.8 percent in 2016 suggesting a significant LULC change during the study period This BE growth of about 116 percent framed the basis for changes in ESV and ES and functions changes. Study further show that between 1995 and 2005, bushland experienced high soil erosion than other LULC classes; this was contrary to the 2005 - 2016 period, in which agriculture and BE displayed high soil erosion levels. From 1995 to 2016, huge loss/displacement in soil fauna experienced in Nematodes (21.7 percent), Earthworms (18.2 percent), and 17.9 in Mites, Collembola and Enchytraeids. Annual population rise by 1.0 percent in the study area between 1995 and 2005, led to BE expansion by 0.3 percent and 0.5 percent loss of vegetation cover respectively. Such change is associated with a loss of 1.6 percent per capita recreation potential and 0.06 percent of ESV. On the other hand, a 2.0 percent annual change of population in the study area between 2005 and 2016 influenced BE expansion by 1.2 percent, a factor that led to vegetation cover loss by 2.0 percent. The declining trend in vegetation cover decreased per capita recreation potential by 2.3 percent and ESV loss by 0.02 percent.

In a nutshell, the relationship between soil, BE and biodiversity is complex, and as the world ecosystem face more urbanization; urban centres are likely to become central sources of ES and values. Attentiveness on biodiversity offset in biodiversity-infrastructures development nexus improves integration of biodiversity habitat strips in the anthropogenic dominated environment. Similarly understanding the intertwined complex interactions between soil ecology and soil erosion maximizes ES production and supply, thru sustainable land use planning.

\section{REFERENCES}

Adhikari, K., \& Hartemink, A. E. (2016). Linking soils to ecosystem services-A global review. Geoderma, 262, 101-111.

Aerts, J. C. J. H., Botzen, W. J. W., Emanuel, K., Lin, N., De Moel, H., \& Michel-Kerjan, E. O. (2014). Evaluating flood resilience strategies for coastal megacities. Science, 344(6183), 473-475.

Al-Bilbisi, H. (2019). Spatial Monitoring of Urban Expansion Using Satellite Remote Sensing Images: A Case Study of Amman City, Jordan. Sustainability, 11(8), 2260.

Alavaisha, E., \& Mangora, M. M. (2016). Carbon stocks in the small estuarine mangroves of Geza and Mtimbwani, Tanga, Tanzania. Int. J. For. Res.,, 2016.

Awad, M. M., Alawar, B., \& Jbeily, R. (2019). A New Crop Spectral Signatures Database Interactive Tool (CSSIT). Data, 4(2), 77.

Baker, M. E., Schley, M. L., \& Sexton, J. O. (2019). Impacts of Expanding Impervious Surface on Specific Conductance in Urbanizing Streams. Water Resour. Res.

Bidegain, I., Cerda, C., Catalán, E., Tironi, A., \& López-Santiago, C. (2019). Social preferences for ecosystem services in a biodiversity hotspot in South America. PloS One, 14(4), e0215715.

Bindu, G., Rajan, P., Jishnu, E. S., \& Joseph, K. A. (2018). Carbon stock assessment of mangroves using remote sensing and geographic information system. Egypt. J. Remote Sens. Sp. Sci.

Butt, T. E., Heywood, C. A., Paul, P., \& Jones, K. G. (2014). Sustainability of and Obsolescence in the Built Environment: Two Contrary Notions. Sustain. J. Rec., 7(2), 116-122.

Carmona, M. (2019). Marketizing the governance of design: design review in England. J. Urban Des., 24(4), 523-555. 
Cordingley, J. E., Newton, A. C., Rose, R. J., Clarke, R. T., \& Bullock, J. M. (2015). Habitat fragmentation intensifies trade-offs between biodiversity and ecosystem services in a heathland ecosystem in southern England. PloS One, 10(6), e0130004.

Costanza, R., d'Arge, R., De Groot, R., Farber, S., Grasso, M., Hannon, B., ... Paruelo, J. (1997). The value of the world's ecosystem services and natural capital. Nature, 387(6630), 253.

de Sa, E., \& Ardern, C. I. (2014). Associations between the built environment, total, recreational, and transit-related physical activity. BMC Public Health, 14(1), 693.

Diesing, M., Mitchell, P., \& Stephens, D. (2016). Image-based seabed classification: what can we learn from terrestrial remote sensing? ICES J. Mar. Sci., 73(10), 2425-2441.

Ekoungoulou, R., Niu, S., Loumeto, J. J., Ifo, S. A., Bocko, Y. E., Mikieleko, F. E. K., ... Liu, X. (2015). Evaluating the carbon stock in aboveand below-ground biomass in a moist central African forest. Appl. Ecol. Environ. Sci, 3(2), $51-59$.

Elmqvist, T., Setälä, H., Handel, S. N., Van Der Ploeg, S., Aronson, J., Blignaut, J. N., ... De Groot, R. (2015). Benefits of restoring ecosystem services in urban areas. Curr. Opin. Environ. Sustain., 14, 101-108.

Gashaw, T., Mebrat, W., Hagos, D., \& Nigussie, A. (2014). Climate change adaptation and mitigation measures in Ethiopia. J Biol Agric Healthc, 2093-2225.

Gombe, K. E., Asanuma, I., \& Park, J.-G. (2017). Quantification of Annual Urban Growth of Dar es Salaam Tanzania from Landsat Time Series Data. Adv. Remote Sens., 6(03), 175.

Gómez-Baggethun, E., \& Barton, D. N. (2013). Classifying and valuing ecosystem services for urban planning. Ecol. Econ., 86, 235-245.

Halmy, M. W. A., Gessler, P. E., Hicke, J. A., \& Salem, B. B. (2015). Land use/land cover change detection and prediction in the north- western coastal desert of Egypt using MarkovCA. Appl. Geogr., 63, 101-112.

Hepelwa, A. S. (2013). Technical efficiency as a sustainability indicator in continuum of integrated natural resources management. Resour. Environ., 3(6), 194-203.

Hui, N., Grönroos, M., Roslund, M., Parajuli, A., Vari, H. K., Soininen, L., ... Sinkkonen, A. (2019). Diverse Environmental Microbiota as a Tool to Augment Biodiversity in Urban Landscaping Materials. Front. Microbiol., 10, 536.

Hurley, P. T., \& Emery, M. R. (2018). Locating provisioning ecosystem services in urban forests: Forageable woody species in New York City, USA. Landsc. Urban Plan., 170, 266-275.

Iqbal, M. F., \& Khan, I. A. (2014). Spatiotemporal land use land cover change analysis and erosion risk mapping of Azad Jammu and Kashmir, Pakistan. Egypt. J. Remote Sens. Sp. Sci., 17(2), 209-229.

Jacoby, R., Peukert, M., Succurro, A., Koprivova, A., \& Kopriva, S. (2017). The role of soil microorganisms in plant mineral nutritioncurrent knowledge and future directions. Front. Plant Sci., 8, 1617.

Kane, K., \& Clark, W. A. V. (2019). Mapping the landscape of urban work: Home-based businesses and the built environment. Environ. Plan. A Econ. Sp., 51(2), 323-350.

Karki, S., Thandar, A. M., Uddin, K., Tun, S., Aye, W. M., Aryal, K., ... Chettri, N. (2018). Impact of land use land cover change on ecosystem services: a comparative analysis on observed data and people's perception in Inle Lake, Myanmar. Environ. Syst. Res., 7(1), 25.

Keller, D. P., Lenton, A., Littleton, E. W., Oschlies, A., Scott, V., \& Vaughan, N. E. (2018). The effects of carbon dioxide removal on the carbon cycle. Curr. Clim. Chang. reports, 4(3), 250265.

Khademagha, P., Aries, M. B. C., Rosemann, A. L. P., \& Van Loenen, E. J. (2016). Implementing 
non-image-forming effects of light in the built environment: A review on what we need. Build. Environ., 108, 263-272.

Koirala, P., Thakuri, S., Joshi, S., \& Chauhan, R. (2019). Estimation of Soil Erosion in Nepal Using a RUSLE Modeling and Geospatial Tool. Geosciences, 9(4), 147.

Kukulska-Kozieł, A., Szylar, M., Cegielska, K., Noszczyk, T., Hernik, J., Gawroński, K., ... Kovács, K. F. (2019). Towards three decades of spatial development transformation in two contrasting post-Soviet cities-Kraków and Budapest. Land Use Policy, 85, 328-339 (11 pages).

Lal, R. (2014). 1 Introduction 2 On-site and off-site effects of accelerated erosion. 2(3), 36-47. https://doi.org/10.1016/S20956339(15)30021-6

Lal, R. (2015). Restoring soil quality to mitigate soil degradation. Sustainability, 7(5), 58755895.

Ligonja, P. J., \& Shrestha, R. P. (2015). Soil erosion assessment in kondoa eroded area in Tanzania using universal soil loss equation, geographic information systems and socioeconomic approach. L. Degrad. Dev., 26(4), 367-379.

Lobora, A. L., Nahonyo, C. L., Munishi, L. K., Caro, T., Foley, C., \& Beale, C. M. (2017). Modelling habitat conversion in miombo woodlands: insights from Tanzania. Journal of Land Use Science, 12(5), 391-403.

Lu, D., Hetrick, S., \& Moran, E. (2010). Land cover classification in a complex urban-rural landscape with QuickBird imagery. Photogramm. Eng. Remote Sens., 76(10), 1159-1168.

Malimbwi, R. E., \& Zahabu, E. (2014). NAFORMA process and biophysical results. http://www.taccire.sua.ac.tz/xmlui/handle/123 $456789 / 450$

Mannan, A., Liu, J., Zhongke, F., Khan, T. U., Saeed, S., Mukete, B., ... Amir, M. (2019). Application of land-use/land cover changes in monitoring and projecting forest biomass carbon loss in Pakistan. Glob. Ecol. Conserv., 17, e00535.

Mkalawa, C. C. (2016). Analyzing dar es salaam urban change and its spatial pattern. Int. J. Urban Plan. Transp., 31(1), 1138-1150.

Mkalawa, C. C., \& Haixiao, P. (2014). Dar es Salaam city temporal growth and its influence on transportation. Urban, Plan. Transp. Res., 2(1), 423-446.

Murdoch, W. W., Chu, F.-I., Stewart-Oaten, A., \& Wilber, M. Q. (2018). Improving wellbeing and reducing future world population. PloS One, 13(9), e0202851.

Neugarten, R. A., Langhammer, P. F., Osipova, E., Bagstad, K. J., Bhagabati, N., Butchart, S. H. M., ... Arrellano, C. G. (2018). Tools for measuring, modelling, and valuing ecosystem services: guidance for Key Biodiversity Areas, natural World Heritage Sites, and protected areas. IUCN.

Nyawade, S. O., Gachene, C. K. K., Karanja, N. N., Gitari, H. I., Schulte-Geldermann, E., \& Parker, M. L. (2019). Controlling soil erosion in smallholder potato farming systems using legume intercrops. Geoderma Reg., 17, e00225.

Olson, K. R., Al-Kaisi, M., Lal, R., \& Cihacek, L. (2016). Impact of soil erosion on soil organic carbon stocks. J. Soil Water Conserv., 71(3), 61A-67A.

Orgiazzi, A., \& Panagos, P. (2018). Soil biodiversity and soil erosion: It is time to get married: Adding an earthworm factor to soil erosion modelling. Glob. Ecol. Biogeogr., 27(10), 1155-1167.

Panagos, P., Van Liedekerke, M., Jones, A., \& Montanarella, L. (2012). European Soil Data Centre: Response to European policy support and public data requirements. Land Use Policy, 29(2), 329-338.

Parris, K. M. (2016). Ecology of urban environments. John Wiley \& Sons. 
Parris, K. M., Amati, M., Bekessy, S. A., Dagenais, D., Fryd, O., Hahs, A. K., ... Marshall, A. J. (2018). The seven lamps of planning for biodiversity in the city. Cities, 83, 44-53.

Pinho, F. F. S., \& Lúcio, V. J. G. (2017). Rubble stone masonry walls in portugal: material properties, carbonation depth and mechanical characterization. Int. J. Archit. Herit., 11(5), 685-702 (17 pages).

Ran, L., Lu, X., Fang, N., \& Yang, X. (2018). Effective soil erosion control represents a significant net carbon sequestration. Sci. Rep., 8(1), 12018.

Rieb, J. T., Chaplin-Kramer, R., Daily, G. C., Armsworth, P. R., Böhning-Gaese, K., Bonn, A., ... Jackson, B. M. (2017). When, where, and how nature matters for ecosystem services: challenges for the next generation of ecosystem service models. BioScience, 67(9), 820-833.

Rizzo, M. (2014). The political economy of an urban megaproject: The bus rapid transit project in Tanzania. Afr. Aff. (Lond)., 114(455), 249-270.

Robinson, D. O., Gaertner, M., \& Papageorgiou, C. (2011). Tanzania: Growth acceleration and increased public spending with macroeconomic stability. Yes Africa Can, 21.

Rwanga, S. S., \& Ndambuki, J. M. (2017). Accuracy assessment of land use/land cover classification using remote sensing and GIS. Int. J. Geosci, 8(4), 611-622.

Sakijege, T., Lupala, J., \& Sheuya, S. (2012). Flooding, flood risks and coping strategies in urban informal residential areas: The case of Keko Machungwa, Dar es Salaam, Tanzania. Jàmbá J. Disas. Risk Stud., 4(1), 1-10.

http://www.taccire.suanet.ac.tz/xmlui/handle/1 $23456789 / 229$ ?show=full

Schmidt, S., Manceur, A. M., \& Seppelt, R. (2016). Uncertainty of monetary valued ecosystem services-value transfer functions for global mapping. PloS One, 11(3), e0148524.
Schreiber, D., Ermel, U. T., Figueiredo, J. A. S., \& Zeni, A. (2016). Analysis of innovation and its environmental impacts on the chemical industry. BAR-Brazilian Adm. Rev., 13(1), 5675.

Senga, H. O. (2014). Land cover change of Coastal Marine Ecosystems: A case study of Zanzibar. Sokoine University of Agriculture.

Seto, K. C., Fragkias, M., Güneralp, B., \& Reilly, M. K. (2011). A meta-analysis of global urban land expansion. Environ. Plan. A Econ. Sp., 6(8), e23777.

Seto, K. C., Güneralp, B., \& Hutyra, L. R. (2012). Global forecasts of urban expansion to 2030 and direct impacts on biodiversity and carbon pools. Proc. Natl. Acad. Sci., 109(40), 1608316088.

Shahraki, A. A. (2017). Regional development assessment: Reflections of the problemoriented urban planning. Sustain. cities Soc., 35, 224-231.

Shanshan, W., Baoyang, S., Chaodong, L., Zhanbin, L., \& Bo, M. (2018). Runoff and Soil Erosion on Slope Cropland: A Review. J. Resour. Ecol., 9(5), 461-471.

Sharma, J., Prasad, R., Mishra, V. N., Yadav, V. P., \& Bala, R. (2018). Land Use and Land Cover Classification of Multispectral LANDSAT-8 Satellite Imagery Using Discrete Wavelet Transform. Int. Arch. Photogramm. Remote Sens. Spat. Inf. Sci., 42, 5.

Susilo, B., Sulastri, R., \& Khikmah, F. (2018). Accuracy Assessment of Land Cover Fraction Map Derived from Landsat 8 Imagery Using Linear Spectral Mixture Analysis Method. IOP Conference Series: Earth and Envi.l Sci., 165(1), 12024. IOP Publishing.

Thomson, G., \& Newman, P. (2018). Urban fabrics and urban metabolism-from sustainable to regenerative cities. Resour. Conserv. Recycl., 132, 218-229.

URT. (2010). National Forest Resources Monitoring and Assessment of Tanzania (NAFORMA) field manual-Biophysical survey. 
NAFORMA document M01-2010. Forestry and Beekeeping Division, Ministry of Natural Resources and Tourism.

van Heezik, Y., \& Brymer, E. (2018). Nature as a commodity: what's good for human health might not be good for ecosystem health. Front. Psychol., 9, 1673.

Wang, Y., Jiang, Y., Zheng, Y., \& Wang, H. (2019). Assessing the Ecological Carrying Capacity Based on Revised Three-Dimensional Ecological Footprint Model in Inner Mongolia, China. Sustainability, 11(7), 2002.

Watkiss, P., Downing, T., Dyszynski, J., Pye, S., Savage, M., Goodwin, J., ... Lynn, S. (2011). The economics of climate change in the United Republic of Tanzania. Global Climate Adaptation Partnership (GCAP).

Xie, G., Zhang, C., Zhen, L., \& Zhang, L. (2017). Dynamic changes in the value of China's ecosystem services. Ecosyst. Serv., 26, 146154.

Yesuph, A. Y., \& Dagnew, A. B. (2019). Soil erosion mapping and severity analysis based on RUSLE model and local perception in the Beshillo Catchment of the Blue Nile Basin, Ethiopia. Environ. Syst. Res., 8(1), 17.

You, H., \& Yang, X. (2017). Urban expansion in 30 megacities of China: Categorizing the driving force profiles to inform the urbanization policy. Land Use Policy, 68, 531-551 (20 pages).

Yuan, S., Zhu, C., Yang, L., \& Xie, F. (2019). Responses of Ecosystem Services to Urbanization-Induced Land Use Changes in Ecologically Sensitive Suburban Areas in Hangzhou, China. Int. J. Environ. Res. Public Health, 16(7), 1124.

Zari, M P. (2018). The importance of urban biodiversity-an ecosystem services approach. Biodivers. Int J, 2(4), 357-360.

Zari, M. P. (2014). Ecosystem services analysis in response to biodiversity loss caused by the built environment. SAPI EN. S. Surv. Perspect. Integr. Environ. Soc., (7.1).
Zari, Maibritt Pedersen. (2019). Devising Urban Biodiversity Habitat Provision Goals: Ecosystem Services Analysis. Forests, 10(5), 391.

Zheng, L.; Wu, H.; Zhang, H.; Duan, H.; Wang, J.; Jiang, W.; Song, Q., (2017). Characterizing the generation and flows of construction and demolition waste in China. Construction and Building Materials, 136, 405-413. 